\section{Detección de ADN de parvovirus B19 en donantes de sangre de tres hospitales en Santiago, Chile}

\author{
JORGE LÉVICAN ${ }^{1,2, a}$, MAURICIO TORRES ${ }^{1, \mathrm{~b}}$, NICOLÁS GAGGERO $^{1, \mathrm{e}}$, \\ ROSA CORVALÁN $^{1, \mathrm{c}}$, ALDO GAGGERO $^{1, \mathrm{~d}}$
}

\section{Parvovirus B19 among blood donors from three hospitals in Santiago, Chile}

Background: Parvovirus B19 (B19) is associated with a wide range of diseases in humans, whose severity depends on the immunological and hematological status of the host. It is transmitted mainly through the airway but also by transfusions. Aim: To determine the B19 DNA carrier frequency in a population of volunteer blood donors from three hospitals blood banks in Santiago, Chile, and to determine the viral load in DNA positive cases. Material and Methods: A total of 477 serum samples were analyzed. The screening of B19 DNA was carried out by nested polymerase chain reaction (PCR) directed to the non-structural region of the virus (NS1). The viral load in positives cases was quantified by NS1 Real Time PCR. Results: Parvovirus B19 was detected in four samples, rendering a frequency of 1:119. The viral loads ranged from less than 2000 to 5,626 $\times 10^{5}$ genome equivalents/ml. Conclusions: Parvovirus B19 was present in four of 477 blood bank blood donors from three hospitals in Santiago.

(Rev Med Chile 2011; 139: 143-149).

Key words: Blood banks; Genome, human; Parvovirus B19, human.



$\mathrm{P}$ arvovirus B19 es agente causal de una amplia gama de manifestaciones clínicas, cuya severidad depende del estado inmunológico y hematológico del hospedero ${ }^{1,2,3}$. La infección por este virus está ampliamente distribuida, lo que se puede inferir por las altas tasas de prevalencia de anticuerpos IgG en la población mundial, la que se presenta en rangos variables y se incrementa con la edad, alcanzando sobre $85 \%$ en población geriátrica ${ }^{2}$.

La forma de contagio más frecuente es mediante secreciones respiratorias y por contacto estrecho persona a persona ${ }^{3}$. Una vía secundaria de transmisión, que reviste especial importancia, es a través de productos sanguíneos obtenidos de donantes aparentemente sanos.

B19 actualmente es reconocido como un importante contaminante de productos de transfusión sanguínea, debido a que sus características biológicas, como tamaño y ausencia de envoltura, lo convierten en un agente muy difícil de eliminar por métodos convencionales. Por este motivo, puede persistir en productos sanguíneos en altas concentraciones luego de tratamientos con detergentes, $\mathrm{pH}$ extremos, inactivación por calor o filtración (excepto nanofiltración) y, como consecuencia de esto, puede llegar a ser transmitido a pacientes susceptibles ${ }^{2}$. Actualmente, existe abundante evidencia de la transmisión de este virus a través de productos elaborados de sangre de donantes aparentemente sanos. Se ha observado seroconversión, infección sintomática y asintomática en pacientes tratados con distintos productos sanguíneos obtenidos de lotes de plasmas contaminados con B19,5,5. Del mismo modo, se ha documentado la transmisión del virus e infección sintomática a través de concentrados de plaquetas provenientes de donantes ${ }^{7}$. 
Estudios de prevalencia en donantes de sangre han detectado la presencia de $\mathrm{ADN}$ viral en amplios rangos, los que fluctúan entre 1 en 167 y 1 en 35.000, dependiendo de la situación epidemiológica y de la técnica de detección empleada. Se ha demostrado la presencia de ADN viral en 1 de 5.950 donantes de sangre en Francia en un período de dos años, valor que se incrementó hasta 1 en 1.420 en período epidémico ${ }^{8}$. Por otra parte, se ha documentado la presencia de genoma viral en 27 de 16.859 donantes de sangre en Bélgica ( 1 en $625)^{17}$. En forma similar, en un estudio realizado en 9.568 unidades de sangre en Estados Unidos de Norteamérica, se demostró la presencia de ADN viral en 11 de ellas $(1 \text { en } 870)^{10}$, al igual que en un estudio realizado en Japón, en el cual se detectó la presencia del virus en 6 de 1.000 donantes de sangre $(1 \text { en 167 })^{11}$.

En Chile no se han realizado estudios para la determinación de prevalencia de ADN de parvovirus B19 en población general. No obstante, estudios de seroprevalencia muestran que $60 \%$ de individuos en edad adulta temprana presentan anticuerpos IgG para este virus, lo que implica una alta tasa de exposición a la infección por B19 en estas edades ${ }^{12}$. A su vez, se ha descrito una prevalencia de anticuerpos IgG de 54,8\% en 400 donantes voluntarios de sangre en la ciudad de Santiago $^{13}$. Estos datos sugieren la posibilidad de que un importante número de individuos, al carecer de anticuerpos protectivos, puedan infectarse y desarrollen la enfermedad en edad proclive a la donación de sangre. El propósito de este trabajo es demostrar la presencia de ADN de B19 en donantes voluntarios de sangre en tres bancos de sangre de hospitales de la ciudad de Santiago, y a la vez determinar la magnitud de la viremia en los individuos que resulten positivos.

\section{Materiales y Métodos}

\section{Muestras}

Muestras de plasma de 477 donantes voluntarios de sangre (rango de edad entre 18 y 65 años, 157 mujeres y 320 hombres) fueron incluidas en este estudio; 377 fueron obtenidas entre abril y julio de 2003 desde los bancos de sangre de los hospitales del Salvador (151) y José Joaquín Aguirre (226), y 100 muestras del banco de sangre del Hospital San José, durante Noviembre y Diciembre de 2006.
Estas incluyeron 146 muestras en el intervalo de edad de 18-27 años, 172 entre 28-37 años, 99 entre 38-47 años y 60 en el grupo de $>48$ años de edad.

Las muestras fueron conservadas a $-80^{\circ} \mathrm{C}$ hasta su utilización. El único criterio de exclusión fue la positividad para algún marcador de rutina de Banco de Sangre.

El presente estudio fue llevado a cabo con la aprobación del Comité de Ética de la Facultad de Medicina de la Universidad de Chile.

\section{Extracción de ADN}

Las muestras de suero fueron sometidas a extracción de $\mathrm{ADN}$ según protocolo descrito por Durigon y $\operatorname{cols}^{14} \mathrm{y}$ los extractos de cada una, fueron conservados a $-80^{\circ} \mathrm{C}$ hasta el momento de su análisis.

\section{Detección de ADN de parvovirus B19}

La detección de $\mathrm{ADN}$ se realizó mediante reacción en cadena de la polimerasa (PCR) en un formato anidado, según protocolo descrito por Durigon y cols ${ }^{14}$, empleado en trabajos previos en nuestro laboratorio ${ }^{15,16}$. Para esto, se utilizaron dos pares de partidores dirigidos a la región no estructural 1 (NS1) del virus, P1 y P6 en la primera ronda de PCR, y P2 y P5 en la segunda ronda ${ }^{14}$. El producto de amplificación se evidenció por la presencia de una banda única de 103 pares de bases.

Como control de extracción y amplificación, en forma paralela y tubo independiente, se realizó PCR del gen humano que codifica para la enzima gliceraldehído fosfato deshidrogenada (GAPDH). Para esto se utilizaron los partidores GAPDH S y GAPDH AS, los que generan un amplicón de 105 pares de bases ${ }^{17}$

Como control positivo para B19, se utilizó un constructo elaborado a partir de la región NS1 del virus, insertado en plasmidio pGemt easy vector (Promega), cuya especificidad de secuencia fue confirmada por análisis de restricción y secuenciación. En cada tanda analítica, se incorporó un blanco constituido por una alícuota de agua sometida a todas las etapas del proceso.

Los productos de PCR fueron sometidos a electroforesis en geles de acrilamida/bisacrilamida $19: 1$ al $8 \%$, a 250 volts por 1,5 horas. Para el revelado, se utilizó tinción de nitrato de plata. Los geles fueron digitalizados mediante escáner y las imágenes se almacenaron en una base de datos para su análisis posterior. 
Parvovirus B19 en donantes de sangre - J. Lévican et al

\section{Cuantificación de copias de genoma de parvovirus $B 19$}

Las muestras que resultaron positivas por PCR anidado, se sometieron a cuantificación mediante técnica de PCR en tiempo real estandarizada en el laboratorio. El formato utilizado fue DNA-binding dye (Sybr Green) en un equipo Light Cycler (Roche), para lo cual se ocuparon los partidores P2 y P6 descritos previamente ${ }^{14}$.

Como calibrador de cuantificación, se usó el constructo NS1 pGEMt easy vector (Promega), cuya cantidad de copias se determinó mediante lectura espectrofotométrica.

Utilizando diluciones seriadas del calibrador, se generó una curva estándar a partir de la relación del parámetro Crossing Point $(\mathrm{CP})$ respecto a la concentración del calibrador para cada dilución. La cuantificación de las muestras positivas por PCR anidada se realizó interpolando el valor de CP de la muestra problema en la curva estándar diseñada anteriormente. Este análisis fue realizado por el software LightCycler 3.5 de Roche en la modalidad Second Derivative Method.

El resultado final de la cuantificación se expresó como número de equivalentes de genoma viral por $\mathrm{ml}$ de muestra.

\section{Resultados}

En 4 de las 477 muestras de suero de donantes analizadas por PCR anidado se detectó ADN de B19 (Tabla 1), evidenciado por la presencia de un producto de amplificación de 103 pares, como se muestra en la Figura 1. De acuerdo a esto, la frecuencia de detección en el grupo de donantes analizados, fue de 1 en 119.

Paralelamente, la detección del gen GADPH, utilizado como control de presencia de DNA, demostró presencia de $\mathrm{ADN}$ amplificable en todas las muestras analizadas, como se observa en la Figura 2 (donantes 21-37), en la cual se visualiza la presencia de una banda única de 105 pares de bases.

Las muestras positivas fueron cuantificadas por PCR en tiempo real, observándose amplificación específica en todos los casos, lo cual se verificó por análisis de melting. La carga viral de los casos positivos fluctuó entre menos de 2000 a 5,626 x $10^{5}$ equivalentes de genoma/ml (Tabla 2 ).

En un trabajo previo, se determinó la prevalencia de anticuerpos IgG anti-B19 en el mismo grupo de donantes que analizó el presente estudio ${ }^{13}$. Salvo el donante 66, en el cual se detectó IgG, los otros donantes (186, 269 y 328) no presentaron anticuerpos contra el virus.

Tabla 1. Distribución de donantes con ADN de parvovirus B19 positivo, según centro asistencial

\begin{tabular}{|lcc|}
\hline Centro asistencial & $\begin{array}{c}\text { Donantes } \\
\text { analizados }\end{array}$ & $\begin{array}{c}\text { ADN } \\
\text { positivo }\end{array}$ \\
\hline José Joaquín Aguirre & 226 & 1 \\
Salvador & 151 & 3 \\
San José & 100 & 0 \\
\hline Total & 477 & 4 \\
\hline
\end{tabular}

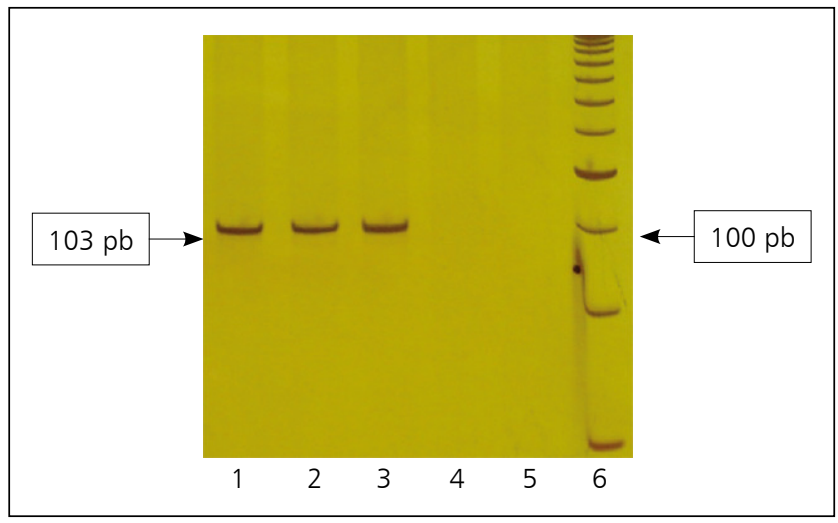

Figura 1. Detección de parvovirus B19 mediante PCR anidado. Carril 1: control positivo parvovirus B19, carriles 2, 3 y 4: donantes 66,269 y 75 respectivamente, carril 5: blanco, carril 6: marcador de peso molecular. 


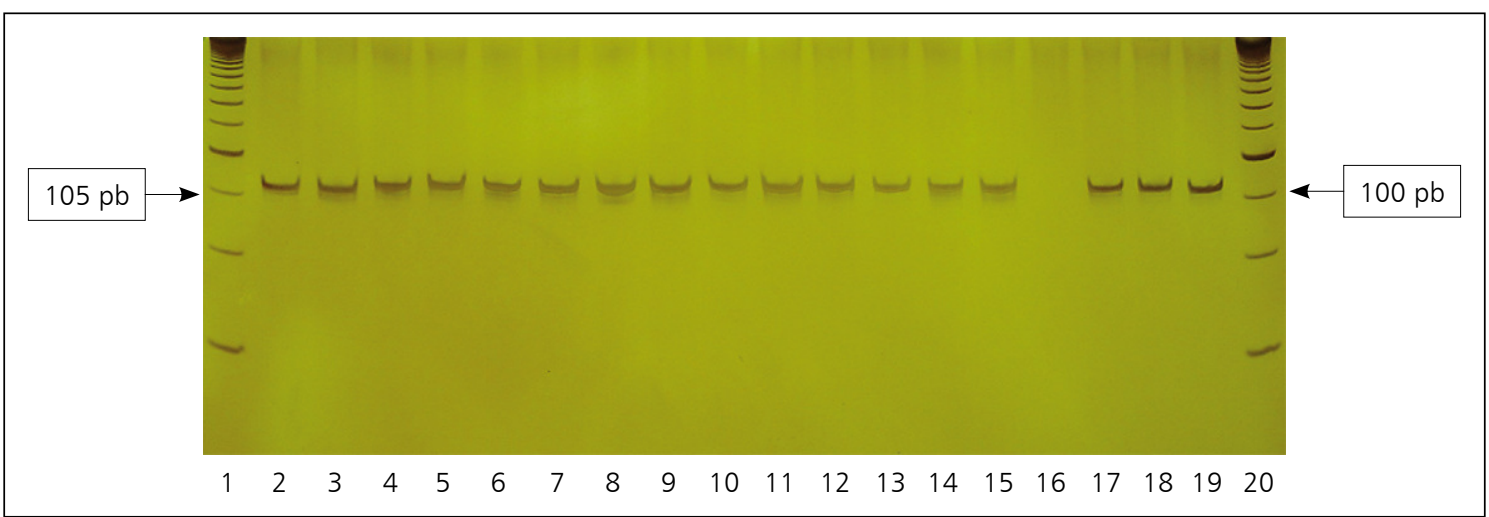

Figura 2. Amplificación del gen GADPH en muestras de donantes de sangre. Carril 2 al 15, donantes Hospital San José 21 al 34 respectivamente, carril 16, blanco; carril 17, 18 y 19, donantes 35, 36 y 37 respectivamente. Carriles 1 y 20, marcador de peso molecular.

Tabla 2. Resultados de cuantificación de carga viral por Sybr Green Light Cycler (Roche) de 4 donantes con ADN positivo para parvovirus B19

\begin{tabular}{|cc|}
\hline Donante & $\begin{array}{c}\text { Carga viral (equivalentes } \\
\text { de genoma/ml) }\end{array}$ \\
66 & $<2.000$ \\
186 & $5,626 \times 10^{5}$ \\
269 & $3,95 \times 10^{5}$ \\
328 & $6,699 \times 10^{4}$ \\
\hline
\end{tabular}

\section{Discusión}

Se detectaron 4 casos positivos en 477 donantes, lo que corresponde a una frecuencia de 1 en 119 donantes $(0,84 \%)$. Esta frecuencia se encuentra entre las más altas reportadas previamente en la literatura para este tipo de poblaciones y es cercana a la descrita por Yoto y cols, quienes notificaron una frecuencia de 1 en 167 y Candotti y cols, que encontraron un rango 0,55 a $1,3 \%{ }^{11,18}$. No obstante, otros autores han documentado presencia de $\mathrm{ADN}$ de $\mathrm{B} 19$ en un amplio rango de frecuencias, las que fluctúan entre 1 en 35.000 y 1 en $625^{10,19-22}$. Estas diferencias serían consecuencia de las distintas técnicas utilizadas y posiblemente, debido también a variables epidemiológicas asociadas a las diferentes poblaciones estudiadas ${ }^{2}$.

La técnica de PCR anidada resultó ser sensible y específica para la detección de ADN de parvovirus
B19 en este tipo de muestras. Según Durigon y $\mathrm{cols}^{14}$, la sensibilidad de este ensayo alcanza de 30 a 3.000 copias de genoma por $\mathrm{ml}$, equivalentes a 0,3 a 30 copias de genoma por reacción $(10 \mu \mathrm{l})$, lo que es considerablemente más sensible que otras técnicas de detección de ADN previamente descritas, como Dot Blot y PCR no anidada.

A diferencia de nuestro estudio, que realizó la detección de B19 en muestras individuales, la estrategia utilizada con mayor frecuencia para búsqueda de B19 en donantes de sangre, consiste en la pesquisa de ADN viral en lotes de plasmas, para luego analizar por separado los componentes de los lotes positivos. El uso de grandes lotes de plasmas, con la consecuente dilución de las muestras, puede resultar en una subestimación de la presencia de $\mathrm{ADN}$ viral por pérdida en la detección de aquellos casos con niveles bajos de viremia ${ }^{11}$. Esto concuerda con el hecho de que los estudios que revelan frecuencias de detección más altas, coinciden en la utilización de pequeños lotes de no más de 10 plasmas, con el fin de evitar el problema de dilución.

Por otra parte, diversos autores reportan la utilización de test de hemaglutinación mediada por receptor (RHA), como primera línea de tamizaje y confirmación de los casos positivos por PCR. RHA reconoce la unión específica del virus con el antígeno $\mathrm{P}$ y su sensibilidad se ha determinado alrededor de los $30 \mathrm{ng}$ de $\mathrm{ADN}$ viral por ml, esto es, alrededor de 1000 veces menos sensible que la PCR anidada ${ }^{14,23}$. Adicionalmente RHA detecta 
principalmente $\mathrm{ADN}$ viral en la fase temprana de la infección, donde se presentan viremias elevadas y no pesquisa aquellos casos con viremias bajas persistentes, lo que se traduce en subestimación de la presencia del virus ${ }^{24}$.

Los aspectos técnicos mencionados pueden explicar las diferencias entre los resultados obtenidos por los distintos estudios de detección de ADN de B19, incluyendo el presente. Sin embargo, otro factor importante a considerar, son las variaciones que se presentan por factores epidemiológicos propios de la naturaleza de la infección viral. En este sentido, se ha demostrado que la infección por B19 presenta una mayor incidencia en épocas de otoño e invierno ${ }^{2,8}$. Junto con estas variaciones estacionales, la incidencia de la infección puede presentar brotes epidémicos cada 3 o 4 años ${ }^{2,23}$. En Chile, hasta la fecha no se han realizado estudios longitudinales para determinar si este comportamiento se presenta en nuestro medio y el diseño del presente estudio tampoco aborda este factor, no obstante es importante destacar que las muestras analizadas fueron recolectadas durante meses de invierno y primavera, por lo que se podría esperar de antemano un nivel alto de infección por B19.

Por otra parte, la cuantificación de los casos positivos para $\mathrm{ADN}$ de $\mathrm{B} 19$ arrojó resultados interesantes. Tres de los 4 casos positivos presentaron carga viral sobre $10^{4}$ equivalentes de genoma $/ \mathrm{ml}$ (Tabla 2). Estos mismos casos no presentaron anticuerpos tipo IgG al momento del análisis y sólo dos de ellos presentaron anticuerpos IgM (datos no mostrados), razón por la que se sugiere que se trata de individuos asintomáticos que cursaban la fase aguda de infección. Por otro lado, se detectó la presencia de $\mathrm{ADN}$ de B19 con carga viral baja en 1 paciente (donante 66, Tabla 2). Este donante presentó anticuerpos IgG al momento del análisis, y ausencia de IgM (dato no mostrado), lo que sugiere que se trataría de un individuo con infección persistente, fenómeno ya descrito en este tipo de poblaciones ${ }^{18,20,25}$. Últimamente, con el uso de técnicas moleculares más sensibles, se ha podido determinar que la presencia de $\mathrm{ADN}$ de B19 en la población general es más frecuente de lo que se había descrito y se ha demostrado que este agente puede persistir en forma crónica en distintos tejidos en el hombre ${ }^{26-27}$. Los mecanismos que posibilitan el fenómeno de persistencia son en la actualidad poco claros. Se ha postulado que B19 podría integrarse al genoma celular del hospedero. Argumentos que apoyan esta idea son aquellos basados en la similitud de este agente con el virus adeno-asociado (AAV), el cual se integra de manera sitio-específica al cromosoma 19 en presencia de adenovirus o herpesvirus ${ }^{28}$. Otras evidencias establecen que B19 podría mantenerse en forma episomal por largos períodos de tiempo, produciéndose partículas virales sólo ocasionalmente, lo que llevaría a una estimulación constante del sistema inmune ${ }^{29}$. Sin embargo, hasta la fecha no existe evidencia directa de que estos mecanismos estén involucrados en la persistencia de B19.

Como conclusión general, podemos decir que queda demostrada la presencia de genoma de B19 en donantes de sangre de centros asistenciales de la ciudad de Santiago de Chile, siendo este el primer reporte en nuestro medio. Sin embargo, en términos generales, los resultados deben ser tomados con cautela ya que, a que a pesar del alto porcentaje de detección revelado, el tamaño de la muestra analizada es pequeña para sacar conclusiones definitivas.

Por otro lado, cabe mencionar que entre los donantes positivos para B19 se encontraron niveles de viremia variable, en un rango de menos de 2.000 a $5,626 \times 10^{5}$ genomas equivalentes $/ \mathrm{ml}$. Las implicancias transfusionales de este fenómeno son significativas en tres de los cuatro casos detectados, debido a que sobrepasan en nivel crítico de carga viral aceptado como límite de riesgo transfusional $\left(10^{3,5} \text { genoma equivalentes } / \mathrm{ml}\right)^{25}$. En cambio, en el donante de carga viral baja, las implicancias transfusionales son discutibles.

En Chile, al igual que en otras partes del mundo, no existe una política oficial para evitar la transmisión vía transfusional de parvovirus B19, y hasta la fecha no existían estudios que confirmaran la presencia de este agente en donantes de sangre en nuestro medio. Por esta razón, la información que entrega el presente trabajo puede servir como base de discusión para el planteamiento de nuevos estudios que profundicen nuestro conocimiento en esta materia, enfocados al diseño de políticas apropiadas a la realidad epidemiológica local.

Agradecimientos: Agradecemos a los Bancos de sangre del Hospital del Salvador, Hospital Clínico José Joaquín Aguirre y Hospital San José, por permitir la obtención de las muestras de suero. 


\section{Referencias}

1. Corcoran A, Doyle S. Advances in the biology, diagnosis and host-pathogen interactions of parvovirus B19. J Med Microbiol 2004; 53: 459-75.

2. Heegaard ED, Brown KE. Human Parvovirus B19. Clin Microbiol Rev 2002; 5: 485-505.

3. Young N, Brown K. Parvovirus B19. N Engl J Med 2004; 350: 586-97.

4. Azzi A, Morfini M, Mannucci PM. The transfusionassociated transmission of Parvovirus B19. Transfus Med Rev 1999; 13: 194-204.

5. Blumel J, Schmidt I, Effenberger W, Seitz H, Willkommen H, Brackmann H, et al. Parvovirus B19 transmission by heat-treated clotting factor concentrates. Transfusion 2002; 42: 1473-81.

6. Yee T, Cohen B, Pasi K, Lee C. Transmission of symptomatic Parvovirus B19 Infection by cloting factor concentrate. Br J Haemathol 1996; 93: 457-59.

7. Cohen B, Beard S, Knowles W, Ellis J, Joske D, Goldman $\mathrm{J}$, et al. Chronic anemia due to parvovirus B19 infection in a bone marrow transplant patient after platelet transfusion. Transfusion 1997; 37: 947-52.

8. Aubin J, Defer C, Vidaud M, Maniez Montreuil M, Flan B. Large-scale screening for human parvovirus B19 DNA by PCR: application to the quality control of plasma for fractionation. Vox Sang 2000; 78: 7-12.

9. Thomas I, Di Giambattista M, Gerard C, Mathys E, Hougardy V, Latour B, et al. Prevalence of human erythrovirus B19 DNA in healthy Belgian blood donors and correlation with specific antibodies against structural and non-structural viral proteins.Vox Sang 2003; 84: 300-7.

10. Jordan J, Tiangco B, Kiss J, Koch W. Human parvovirus B19: prevalence of viral DNA in volunteer blood donors and clinical outcomes of transfusion recipients. Vox Sang 2000; 78: 132.

11. Yoto Y, Kudoh T, Haseyama K, Suzuki N, Oda T, Katoh $\mathrm{T}$, et al. Incidence of human parvovirus B19 DNA detection in blood donors. Br J Haematol 1995; 91: 1017-18.

12. Abarca K, Cohen Bj, Vial P. Seroprevalence of parvovirus B19 in urban Chilean children and young adults, 1990 and 1996. Epidemiol Infect 2002; 128: 59-62.

13. Gaggero A, Rivera J, Calquin E, Larrañaga C, Leon O, Diaz P, Gaggero N. Seroprevalencia de anticuerpos IgG contra parvovirus B19 en donantes de sangre de hospitales en Santiago, Chile. Rev Med Chile 2007; 135: 443-48.

14. Durigon E, Erdman D, Gary G, Pallansch M, Torok T, Anderson L. Multiple primer pairs for Polymerase chain reaction (PCR) amplification of human parvovirus B19 DNA. J Virol Methods 1993; 44: 155-65.
15. González B, Larrañaga C, León O, Díaz P, Miranda M, Barria M, et al. Parvovirus B19 may have a role in the pathogenesis of Juvenile Idiopathic Arthritis. J Rheumatol 2007; 34: 6-11.

16. Larrañaga C, León O, Díaz P, Miranda M, Norambuena X, Pérez M, et al. Parvovirus B19 infection in Chile: behavior of markers of infection and immunity in patients with clinical manifestations associated with the virus. J Med Virol 2007; 79: 1927-34.

17. Stefanoff C, Hassan R, González A, Andrade L, Tabak D, Romano S, et al Laboratory Strategies for Efficient Handling of Paraffin-Embedded Tissues for Molecular Detection of Clonality in Non-Hodgkin Lymphomas. Diag Mol Pathol 2003; 12: 79-87.

18. Candotti D. Identification and Characterization of Persistent Human Erythrovirus Infection in Blood Donor Samples. J Virol 2004; 78: 12169-178.

19. Hitzler W, Runkel S. Prevalence of human parvovirus B19 in blood donors as determined by a haemagglutination assay and verified by the polymerase chain reaction. Vox Sang 2002; 82: 18-23.

20. Mcomish F, Yap P, Jordan A, Hart H, Cohen B, Simmonds P. Detection of parvovirus B19 in donated blood: a model system for screening by polymerase chain reaction. J Clin Microbiol 1993; 31: 323-28.

21. Thomas I, Di Giambattista M, Gerard C, Mathys E, Hougardy V, Latour B, et al. Prevalence of human erythrovirus B19 DNA in healthy Belgian blood donors and correlation with specific antibodies against structural and non-structural viral proteins. Vox Sang 2003; 84: 300-7.

22. Wakamatsu C, Takakura F, Kojima E, Kiriyama Y, Goto $\mathrm{N}$, Matsumoto K, et al. Screening of blood donors for human parvovirus B19 and characterization of the results. Vox Sang 1999; 76: 14-21.

23. Zaaijer H, Koppelman M, Farrington C. Parvovirus B19 viraemia in Dutch blood donors. Epidemiol Infect 2004; 132: 1161-6.

24. Sakata H, Ihara H, Sato S, Kato T, Ikeda H, Sekiguchi S. Efficiency of Donor Screening for Human Parvovirus B19 by the Receptor-Mediated Hemagglutination Assay Method. Vox Sang 1999; 77: 197-203.

25. Brown Ke, Young Ns, Alving Bm, Barbosa LH. Parvovirus B19: Implications for transfusion medicine. Transfusion 2001; 41: 130-5.

26. Soderlund M., Von Essen R., Haapasaari J, Kiistala U, Kiviluoto 0, Hedman K. Persistence of parvovirus B19 DNA in synovial membranes of young patients with and without chronic arthropathy. The Lancet 1997; 349: 1063-65.

27. Heegaard E, Petersen B, Heilmann C, Hornleth A. Prevalence of Parvovirus B19 and V9 DNA and Antibodies in 
Parvovirus B19 en donantes de sangre - J. Lévican et al

Paired Bone Marrow and Serum Samples from Healthy Individuals. J Clin Microbiol 2002; 40: 933-6.

28. Lefere J, Servant-Delams A, Candotti D, Mariotti M, Thomas I, Brossard Y, et al. Persistent B19 infection in immunocompetent individuals: implications for trans- fusion safety. Blood 2005; 106:2890-2895.

29. Norbeck O, Isa A, Pölhlmann C, Broliden K, Kasprowicz V, Bowness P, et alL. Sustained CD8+ T-Cell Responses Induced after Parvovirus B19 Infection in Humans. J Virol 2005; 79: 12117-21. 